\title{
Online Learning in the Era of Pandemic: Solution or Disaster?
}

\author{
Dhion Meitreya Vidhiasi \\ AkademiMaritim Nusantara Cilacap, Cilacap \\ mvdhion@gmail.com
}

Diterima 24 Agustus 2021, direvisi 24 September 2021, diterbitkan 06 Oktober 2021

\begin{abstract}
The 4.0 industry has been examined, marking a development in IT, including the internet, big data and artificial intelligence. Everyone was not distinguished from technology by the development of IT in the $21^{\text {st }}$ century. Different opinions from various parties to online learning come from face-to-face shifting paradigms. This sort of learning paradigm has multiple advantages and disadvantages to reach the aim of learning itself. This study seeks to assess the perspective of learners of online learning in this context in a COVID-19 pandemic. The study focuses on students of Akademi Maritim Nusantara Cilacap in the English Conversation subject. The instruments used are semi-structured interviews. The researcher asked the students about the Covid-19 outbreak via the WhatsApp service. The research design employed in this research was a case study. The online study is unbelievably advantageous in the heart of the pandemic. AMN Cilacap has selected the Google Classroom Service as its Learning Management System. They will receive new terminology, knowledge, and technical skills. Thus, when they graduate in the future, students will no longer have problems using their primary app for education. Online learning is more effective than offline learning for a particular objective, information, skills, and students. Combining the benefit of online and offline teaching approaches known as combined learning will help overcome the potential limitations of online learning in the professional school of AMN Cilacap. But a mix of online and offline learning, notwithstanding the volatility of online, maybe the best option to maximize its worth.
\end{abstract}

Keywords: COVID-19, Online Learning, Offline Learning, Learning Management System.

\section{Abstrak}

Kehidupan manusia terus berkembang dengan cepat. Revolusi Industri 4.0 telah terjadi dimana hal tersebutditandai dengan perkembangan di bidang IT, termasuk Internet, Big Data, dan Artificial Intelligence. Setiap orang terkoneksi satu sama lain dengan adanya perkembangan IT di abad ke-21. Perbedaan pendapat dari berbagai pihak terhadap pembelajaran daring datang dari pergeseran paradigma pembelajaran tatap muka. Paradigma pembelajaran semacam ini memiliki banyak kelebihan dan kekurangan untuk mencapai tujuan pembelajaran itu sendiri. Penelitian bertujuan untuk menilai perspektif pembelajar pembelajaran daringdi masa pandemi COVID-19. Penelitian ini berfokus pada mahasiswa Akademi Maritim Nusantara Cilacap pada mata kuliah English Conversation. Instrumen yang digunakan adalah wawancara semi terstruktur. Peneliti menanyakan kepada mahasiswa tentang pembelajaran masa COVID-19 melalui layanan WhatsApp. Desain penelitian yang digunakan dalam penelitian ini adalah studi kasus. Hasilnya menunjukkan bahwapembelajaran daring sangat menguntungkan di tengah pandemi. AMN Cilacap telah memilih Layanan Google Classroom sebagai Learning Management System-nya.Mereka akan menerima terminologi, pengetahuan, dan keterampilan teknis baru. Dengan demikian, ketika mereka lulus di masa depan, siswa tidak akan lagi kesulitan menggunakan aplikasi utama mereka untuk pendidikan. Pembelajaran daring lebih efektif daripada pembelajaran luring untuk tujuan, informasi, keterampilan, dan siswa tertentu. Menggabungkan manfaat pendekatan pengajaran daring dan luring yang dikenal sebagai pembelajaran campuran akan membantu mengatasi potensi keterbatasan pembelajaran online di AMN Cilacap. Perpaduan pembelajaran daring dan luring merupakan pilihan terbaik untuk memaksimalkan tujuan pembelajaran yang diinginkan.

Kata kunci: COVID-19, Pembelajaran Daring, Pembelajaran Luring, Learning Management System 


\section{Introduction}

Industry 4.0, which marks progress in information technologies such as the internet, big data, and artificial intelligence, has been analyzed.The evolution of IT in the 20th century did not distinguish everyone from technology. Under these situations, education is necessary to respond positively and adapt to developments[1]. One of the strategies every government needs to pursue in tackling the troubled era of the $21^{\text {st }}$ century is aimed at providing training and education to enhance the skills and adaptations, as well as to increase the capacity to do things and also to educate them to become IT experts [2].

In different activities, the use of technology in education is regularly addressed. Some disagreed with the frequent exaggeration, regardless of the good or bad consequences on its users by using information technologies [3] and [4].Informatique may be utilized to improve the quality of the learning and make IT a tool for providing learning resources, disseminating materials via the internet, and training life skills [5].

When the COVID-19 pandemic took place, everything changed, and all the activities carried out both on the job and the home study was distributed to other nations in the globe in Wuhan, China. This is also true of Indonesia. So, a system of learning that was originally face-toface has turned into a distant learning system.

A remote learning system was initially used as a description of teaching systems using IT. Recently, there has been a great deal of study on online learning in primary schools, such as zoom, a Google classroom [6], [7]. Various studies conducted in online learning have shown that it is effective and can be used in education. The development of online learning helps students significantly explore how to use selfregulatory strategies [8], [9]. Online learning is a technique to be successful for education because most of its application is already understood in secondary and higher education.

Furthermore, the adoption of online learning in only a short time is a test. Online learning will have a substantial impact on its efficacy. It is evident. Emergency conditions mean that everyone needs to study online.
They were traditionally teaching activities in classrooms using a technique that is turned into an online learning system. To prevent the spreading of COVID-19, the concept of the social distance and the physical separation from expanding, everyone has to remain home. Therefore, instructors and students must remain at home and yet complete their obligations. Teachers must continue to teach students creatively and imaginatively to inform them about good education.

The shifting models from face to face provide diverse views from different parties to online learning. There are some benefits and disadvantages of this type of learning model so that the objective of learning itself may be achieved.Smart \&Cappel, who have completed online studying modules before a class discussion, is investigating their opinions on integrating components into two Bachelor of Studies business courses [10]. The results show that online modules were far better evaluated than participants in an elective course.Overall, optional participants considered online modules slightly favorable, whereas, in mandatory classes, they were rated marginally negative. While Swan [11] argues in her study that current developments in the use of remote learning and e-learning might marginalize distant learners. Thompson argues that language's capacity strongly to affect our thinking is worthy of consideration.

Sun and Chen [12] offer practical advice to people who want to build online courses to take informed decision-making in the implementation phase to prevent these allegations. The authors stated that effective online learning depends on 1) a well-planned course, a motivated interaction of instructors and learners, well-prepared and fully supported teachers; 2) the establishment of an understanding of online learning communities; and 3) quick technological progress.This aim stimulates an ongoing discussion of appropriate methods to strengthen institutions and the effectiveness of the faculty in transition to online teaching. Holmes and Gardner [13] summarizes the fact that e-learning is able, employing the interaction appropriate to community education, cultural diversity, and globalization, to evaluate the students as they learn and at the same time to enhance their experience in education, and eradicate the boundaries of time and place. The essential 
features of e-learning in education and its advantages are that it focuses on the learners.

The instructor is essential for the success of an education since the teacher touches pupils directly in educational terms [14]. The instructor must also guarantee that the learning process works effectively because of its professionalism and responsibility.Under these situations, however, teaching and learning activities become very dilemmatic. Therefore, it demands that teachers carry out online learning activities, so educational researchers need to study how the instructor includes online teaching.

Many factors impact the efficacy of online learning. Some elements cause hurdles to learning online, such as administrative concerns, social contact, academic capabilities, technical abilities, learners' motivation, time and study assistance, technological problems, costs, and internet connection. Additional variables may lead to low-quality online learning, such as inadequate multimedia design and organization.

The epidemic of this COVID-19 has a perspective of learners in its own right. The value of student perceptions is acknowledged to contribute to the performance of this online learning process by teachers and institutions to maintain the operating optimal and keep COVID-19 transmitted broadly. Therefore, this research aims to evaluate learners' perception of online learning in a COVID-19 pandemic from this backdrop.

\section{Research Methodology}

The qualitative research used to describe the study is based on descriptive data, which does not utilize statistical techniques [15]. Statistics are not used to analyze qualitative research information, but rather the inquirer examines words or pictures. The qualitative researcher analyzes the terms to organize them into a greater understanding, as codes, groups, or topics, rather than depending on statistical techniques. The study focuses on the learners of AkademiMaritim Nusantara Cilacap's English Conversation. Semi-structured interviews are the instruments utilized. The researcher questioned learners using the WhatsApp application for the Covid-19 epidemic.A case study was the research design used in this investigation. An ethnographic version is a case study in which the researcher conducts a thorough analysis of an abounding system based on comprehensive data
collection.Braun and Clarke's [16] theoretical analyses outline an iterative method of moving from unclear data to a map of the most relevant topics within the data to analyze the data. The technique has six stages: familiarization, beginning code generation, the search for issues, topic review, definition and naming, and report production.

\section{Findings and Discussion}

This study aims to explore learners' perceptions of the online learning system during the COVID-19 pandemic. The outcomes of the analytical data gathered in interviews on this topic are presented below.

In the thick of the epidemic, online study is incredibly beneficial. As its Learning Management System, AMN Cilacap has adopted the Google Classroom service. With this LMS, students are educated to work on the internet and paper. They will get new terminology, information, and technical competence. As a result, students will no longer have issues utilizing the primary application for schooling and education when they graduate in the future.The talk was greatly liked online. However, Internet access is an issue. The difficulty is that the internet is available, and various students are financially qualified. Anybody can buy a data plan from the internet, and some people cannot even buy it.

The use of Google Classroom makes it easier for students to see the value given by the lecturer in charge of the subject in question. Assessment can be done directly in Google Classroom. It also makes it easier for lecturers who often forget the assessments because of the high intensity of work.

But there are also issues with online lectures. Online learning,mainly consisting of static, noninteractive learning resources like offline learning, was not generally significantly distinguished from offline learning. Furthermore, in the included studies, knowledge and skills cover just a tiny portion of the learning aims. Online education may not function better than offline education on the subjects to be studied. It is quite conceivable.In addition, objective evaluation tools could not measure the AMN Cilacapstudents advanced capacities. Therefore, online learning may be just as efficient as offline learning if learning goals are straightforward. 
In a similar vein, we cannot yet imagine whether online learning works better than offline learning between different curricula before new evidence emerges. This type of currency, which usually primarily associates with learning goals, can also affect online and offline learning effectiveness.

The fast expansion of higher education online learning also profited from the potential cost reductions of endless pupils. In specific ways, online learning may not compete with some features of conventional offline learning, such as interactive learning between teachers and students. Such constraints might provide students with an opportunity to acquire selflearning skills via IT.

The efficacy of online learning variedfor a certain goal, knowledge, skills, and students is as or more efficient than offline learning. Combining the advantages of online and offline teaching techniques termed combined learning may be beneficial to overcome the possible limits of online learning at AMN Cilacap, known as vocational schools. However, to optimize their value, a combination of online and offline learning may be the best possible, notwithstanding the uncertainty of online learning.

\section{Conclusion}

Even all the research articles studied did not indicate that online education was better than offline learning. Neither study demonstrated that online learning was less effective than offline, irrespective of the statistical techniques used. We need to realize that online learning has its advantages in increasing students' learning and must be regarded as a possibility at the vocational level of learning. The implementation of online learning in the era of pandemic neither solution nor disaster. Significant consideration should be made of conceptual design concepts, learning goals and preferences, and characteristics of students for digital learning to guarantee online learning efficiency.

\section{Acknowledgment}

The author would like to thank the Akademi Maritim Nusantara Cilacap for supporting the author so that this research can be published.

\section{Daftar Pustaka}

[1] Anwar, M. (2018). Inovasi Sistem Pendidikan. Inspiratif Pendidikan, 7(2), 161-170. https://doi.org/10.24252/ip.v7i2.7851

[2] Janssen, M., \& van der Voort, H. (2016). Adaptive Governance: Towards a Stable, Accountable and Responsive Government. Government Information Quarterly, 33(1), $1-5$. https://doi.org/10.1016/j.giq.2016.02.003

[3] Selwyn, N. (2016). Minding Our Language: Why Education and Technology is Full of Bullshit ... and What Might be done about it. Learning, Media and Technology, 41(3), 437-443.

https://doi.org/10.1080/17439884.2015.101 2523

[4] Budiman, H. (2014). Peran Teknologi Informasi dan Komunikasi dalam Pendidikan. Al-Tadzkiyyah: Jurnal Pendidikan Islam, 8(1), 31-43. https://doi.org/https://doi.org/10.24042/atjpi .v8i1.2095

[5] Cholik, C. A. (2017). Pemanfaatan Teknologi Informasi dan Komunikasi untuk Meningkatkan Pendidikan di Indonesia. Syntax Literate : Jurnal Ilmiah Indonesia, 2(6), 21-30.

[6] Beach, P. (2018). Examining Elementary Teachers' Use of Online Learning Environments: An Exploratory Study. Journal of Research on Technology in Education, 50(1), 34-47. https://doi.org/10.1080/15391523.2017.138 3216

[7] Yanti, M. T., Kuntarto, E., \& Kurniawan, A. R. (2020). Pemanfaatan Portal Rumah Belajar Kemendikbud sebagai Model Pembelajaran Daring di Sekolah Dasar. ADI WIDYA: Jurnal Pendidikan Dasar, 5(1), 61-68. https://doi.org/http://dx.doi.org/10.25078/a w.v5i1.1306

[8] Larson, L., \& Vontz, T. (2018). An Alternative Pathway to Elementary Teaching. Educational Considerations, 44(1), 1-6. https://doi.org/10.4148/01469282.2164

[9] Delen, E., \& Liew, J. (2016). The Use of Interactive Environments to Promote Self- 
regulation in Online Learning: A Literature Review. European Journal of Contemporary Education, 15(1), 24-33. https://doi.org/10.13187/ejced.2016.15.24

[10] Smart, K., L., \& Cappel, J. (2006). Students' perceptions of online learning: A comparative study. Journal of information technology education, 5, 201-219.

[11] Swan, K. (2019). Research on online learning. Research Center for Educational Technology Kent State University.

[12] Sun, A., \& Chen, X. (2016). Online education and its effective practice: A research review. Journal of Information Technology Education: Research, 157-190.

[13] Holmes, B., \& Gardner, J. (2006). ELearning: Concepts and Practice. London: SAGE Publications.

[14] Rusman. (2013). Model-model Pembelajaran, Mengembangkan Profesionalisme Guru. Jakarta: Rajawali Press.

[15] Creswell, J. W. (2010). Research Design: Pendekatan Kualitatif, Kuantitatif, dan Mixed. Yogyakarta: Pustaka Pelajar.

[16] Braun, V., \& Clarke, V. (2006). Using thematic analysis in psychology. Qualitative Research in Psychology, 3(2), 77-101. 